\title{
EVALUASI PROSES PEMBELAJARAN READING PADA MATA KULIAH BAHASA INGGRIS II DI JURUSAN TARBIYAH STAIN KUDUS
}

\author{
Syaiful Mujab \\ APII (Asosiasi Pendidik Islam Indonesia), \\ Jawa Tengah, Indonesia \\ saifamujab@gmail.com
}

\begin{abstract}
Abstrak
Perkembangan kegiatan belajar mengajar harus dievaluasi untuk mengetahui sukses tidaknya sebuah pembelajaran. Evaluasi ini harus dilakukan karena pengajaran sekarang tentunya akan mempengaruhi proses belajar selanjutnya. Penelitian ini bertujuan untuk mengetahui bagaimana hasil evaluasi pembelajaran mata kuliah Bahasa Inggris II (reading) di STAIN Kudus dan bagaimana tawaran silabi dan SAP mata kuliah bahasa Inggris II untuk program studi PGMI dan PGRA. Metode penelitian ini adalah evaluatif yang difokuskan pada evaluasi konteks, evaluasi proses, dan evaluasi produk. Subyek dalam penelitian ini dilakukan dengan teknik purposive sampling. Hasil penelitian ini menunjukkan bahwa evaluasi pembelajaran mata kuliah Bahasa Inggris II di STAIN Kudus sudah berjalan dengan baik. Hal ini dibuktikan adanya beberapa indikator. Hasil kedua adalah tawaran silabi dan SAP Bahasa Inggris II untuk PGMI da PGRA seharusnya dilakukan perbaikan dan penyesuaian dengan kompetensi yang diharapkan dari para lulusan nantinya.
\end{abstract}

Kata kunci: evaluasi pembelajaran, English II (reading) 


\begin{abstract}
TEACHING SYSTEMEVALUATION OF "BAHASA INGGRIS II" (ANALYSIS STUDY ON READING LEARNING PROCESS IN EDUCATION DEPARTMENT, STAIN KUDUS. The improvement of teaching and learning process should be evaluated to determine the success or failure of the learning process. It should be carried out because it will affect the learning process further. This research had purposes to know how the teaching and learning evaluation of Reading in STAIN Kudus and how is the syllabi dan lesson plan of Reading for Education of Islamic Elementary School and Kindergarten Teacher. The method of this research was evaluative because it was focused on Context Evaluation, Process Evaluation and Product Evaluation. The result showed that the teaching and learning evaluation of Reading in STAIN Kudus run well. It was prooved by some indicators. The second result showed that syllabi dan lesson plan of Reading for Education of Islamic Elementary School and Kindergarten Teacher needs to be improved and adapted with the students competence.
\end{abstract}

Keywords: learning evaluation, English II (reading)

\title{
A. Pendahuluan
}

Sebagai mahluk sosial, manusia selalu berhubungan dan berkomunikasi dengan manusia lain. Media komunikasi yang paling efektif untuk dipakai adalah bahasa. Dengan menggunakan bahasa, mereka bisa menyatakan maksud, ide, pikiran, dan gagasannya agar lebih bisa dipahami dengan tepat maknanya oleh manusia lain di seluruh penjuru dunia yang berbeda. Oleh karena itu kita bisa mengatakan bahwa bahasa adalah alat komunikasi dengan orang lain. Seperti halnya yang dikatakan oleh Keraf (1997: 1) bahwa bahasa adalah alat komunikasi antara anggota masyarakat yang berupa simbol bunyi yang dihasilkan oleh alat ucap manusia.

Di era globalisasi ini kita dituntut untuk tidak hanya bisa memahami bahasa nasional tetapi juga diharapkan bisa memahami dan menggunakan bahasa internasional. Bahasa Inggris adalah salah satu bahasa internasional yang diajarkan secara luas di berbagai negara dunia ini. Banyak penduduk di berbagai negara memakai bahasa Inggris sebagai alat komunikasi dalam berbagai pertemuan penting tingkat internasional. Dalam bidang pendidikan, bahasa Inggris mempunyai andil besar karena hampir semua buku teks dalam 
berbagai disiplin ilmu ditulis dalam bahasa Inggris, yakni dari jenjang pendidikan dasar sampai di perguruan tinggi. Oleh karena itu, bahasa Inggris mempunyai peranan yang sangat penting dalam memasuki era globalisasi. Fungsinya tidak hanya sebagai alat atau media untuk berkomunikasi antar bangsa tetapi semakin luas dan penting, yaitu sebagai bahasa ilmu pengetahuan, teknologi, sosial-ekonomi, budaya, bahkan seni. Sebagai bahasa global, bahasa Inggris memegang fungsi dan peran yang sangat besar. Implikasinya adalah semakin banyak orang yang berusaha untuk bisa belajar bahasa Inggris agar mereka mampu untuk berkomunikasi dengan menggunakan bahasa Inggris dengan baik.

Dalam dunia pendidikan di perguruan tinggi diharapkan mahasiswa dibekali dengan ilmu keterampilan berbahasa Inggris sebagai modal untuk menghadapi persaingan global pasar bebas. Dengan demikian mata kuliah bahasa Inggris seharusnya dimasukkan kedalam kurikulum di perguruan tinggi. Dalam pasal 38, ayat (3) juga disebutkan tentang kurikulum pendidikan tinggi yang bersangkutan dengan mengacu pada standar nasional pendidikan untuk setiap prodi. Dalam Surat Keputusan Menteri Pendidikan Nasional RI No.232/ U/2000 tentang pedoman penyusunan kurikulum pendidikan tinggi, dan kurikulum inti Pendidikan Tinggi serta penilaian hasil belajar mahasiswa, Pemerintah dalam hal ini Mendiknas, memberi keleluasaan kepada pengelola lembaga pendidikan tinggi untuk mengembangkan kurikulum mereka sendiri. Pemerintah hanya memberikan rambu-rambu pedoman pengembangannya, selain itu disebutkan pula bahwa bahasa Inggris masuk ke dalam kelompok Mata Kuliah Pengembangan Kepribadian (MPK).

Selain itu, alasan bahasa Inggris sebagai bahasa asing masih harus dijadikan sebagai mata kuliah yang wajib dipelajari di semua jurusan atau program di seluruh fakultas di perguruan tinggi tiada lain karena Undang-undang Nomor 20 tahun 2003 tentang Pendidikan Nasional, Pasal 33 ayat (3) menyatakan bahasa asing dapat digunakan sebagai bahasa pengantar pada satuan pendidikan tertentu untuk mendukung kemampuan berbahasa asing peserta didik. Hal ini dimaksudkan agar peserta didik dibekali bahasa asing khususnya bahasa Inggris untuk dijadikan sebagai bahasa pengantar mereka di dalam menghadapi era globalisasi, sehingga mereka bisa menatap 
masa depan setelah mereka menempuh pendidikan tinggi.

Kurikulum dan materi pengajaran merupakan faktor utama dalam proses belajar-mengajar. Kurikulum merupakan kunci dalam pemilihan materi pengajaran. Sekolah Tinggi Agama Islam Negeri Kudus (STAIN Kudus) merupakan salah satu pendidikan tinggi agama Islam yang juga mengaplikasikan bahasa Inggris sebagai bahasa pengantar di dalam kurikulumnya. STAIN Kudus saat ini terdiri dari 4 jurusan dan 12 program studi (Prodi) yang diantaranya yaitu jurusan Tarbiyah, Syariah, Dakwah, dan Ushuluddin. Semua jurusan tersebut diatas masing-masing memasukkan bahasa Inggris sebagai mata kuliah pengembangan kepribadian (MKK). Jurusan Tarbiyah terdiri dari program studi Pendidikan Agama Islam (PAI), Pendidikan Bahasa Arab (PBA), dan juga program studi baru yaitu Pendidikan Guru Madrasah Ibtidaiyah (PGMI) dan Pendidikan Guru Raudlatul Athfal (PGRA).

Kurikulum di semua jurusan di STAIN Kudus, untuk mata kuliah bahasa Inggris dibagi menjadi 2 yaitu, mata kuliah Bahasa Inggris I dan Bahasa Inggris II. Mata kuliah Bahasa Inggris I lebih difokuskan pada penguasaan tata bahasa Inggris (grammar), sedangkan mata kuliah bahasa Inggris II lebih ditekankan pada pemahaman membaca (reading). Selain itu untuk mendukung kedua mata kuliah tersebut, juga ditetapkan mata kuliah praktikum bahasa Inggris yang lebih diutamakan pada pengunaan praktek percakapan dalam menggunakan bahasa Inggris. Ketiga mata kuliah tersebut dirasa sudah cukup memberikan bekal kepada mahasiswa dalam menghadapi era globalisasi sekarang ini.

Pada dasarnya sebuah usaha harus dipantau tingkat keberhasilannya guna mengukur efektifitas proses kegiatan yang diinginkan melalui faktor-faktor pendukungnya. Oleh karena itu, dalam peningkatan proses belajar mengajar perlu adanya suatu evaluasi pembelajaran untuk menentukan sukses atau tidaknya proses pembelajaran yang dilakukan selama ini sekaligus mempengaruhi proses pembelajaran selanjutnya. Hal ini dikarenakan evaluasi pembelajaran dapat menjadi sumber informasi dan pegangan bagi pendidik, sekolah, peserta didik dan orang tua untuk meningkatkan mutu prestasi dan motivasi kegiatan pembelajaran. Selain itu hasil evaluasi bisa memberikan masukan-masukan untuk pengembangan 
mata kuliah tersebut misalnya adalah penyesuaian kebutuhan penyusunan silabi dan SAP bagi program studi baru.

Berdasarkan latar belakang diatas, maka peneliti tertarik untuk meneliti evaluasi pembelajaran mata kuliah bahasa Inggris II guna peningkatan pengajaran berikutnya. Dari hasil evaluasi pembelajaran mata kuliah bahasa Inggris yang proses pembelajarannya sudah lama dilakukan diharapkan bisa memberi perubahan dalam penyusunan Silabi dan SAP bahasa Inggris II untuk program studi baru yaitu program studi Pendidikan Guru Madrasah Ibtidaiyah (PGMI) dan program studi Pendidikan Guru Raudlatul Athfal (PGRA) di STAIN Kudus. Oleh karena itu, fokus permasalahan yang akan diambil berkaitan dengan evaluasi pembelajaran bahasa Inggris II yaitu tentang pemahaman membaca dan penyusunan Silabi dan SAP untuk mata kuliah bahasa Inggris II prodi PGMI dan PGRA.

Dari latar belakang masalah di atas maka dapat dirumuskan permasalahan yang muncul diantaranya adalah sebagai berikut:

1. Bagaimanakah hasil evaluasi pembelajaran Mata kuliah Bahasa Inggris II STAIN Kudus ditinjau dari perspektif sistem pembelajarannya?

2. Bagaimana tawaran Silabi dan SAP matakuliah bahasa Inggris II untuk prodi PGMI, dan untuk prodi PGRA?

Penelitian ini bertujuan untuk mengevaluasi sistem pembelajaran mata kuliah bahasa Inggris II di STAIN Kudus. Metode penelitian ini adalah evaluatif yang difokuskan pada evaluasi konteks (Context Evaluation), evaluasi proses (Process Evaluation), dan evaluasi produk (Product Evaluation). Selain itu penelitian ini memerlukan berbagai teknik pengumpulan data dalam fokus yang melibatkan suatu pendekatan interpretatif dan wajar terhadap setiap pokok permasalahannya. Menurut Denzim dan Lincoln dalam Arifin (2011: 140-141) menerangkan bahwa pengumpulan dan penggunaan berbagai data empirik melalui studi kasus, pengalaman pribadi interaksional dari visual yang menggambarkan momen rutin dan problematis, serta maknanya dalam kehidupan individual dan kolektif, diperlukan penelitian kualitatif.

Penelitian ini dilakukan di STAIN Kudus beralamatkan di Jalan Jl. Conge Ngembalrejo PO. BOX. 51 Bae Kudus 59322 Telp. 
(0291) 432677, 438818 Fax. (0291) 441613. Sumber data dalam penelitian adalah subyek darimana data dapat diperoleh. Sumber data penelitian ini adalah manusia dan bukan manusia (Miles dan Huberman, 1992: 2). Sumber data manusia berfungsi sebagai subjek dan informan kunci. Sumber data manusia diperoleh dari beberapa informan kunci yaitu dosen mata kuliah bahasa Inggris dan mahasiswa. Sumber data bukan manusia berupa dokumen-dokumen yang relevan dengan fokus penelitian. Penentuan informan dalam penelitian ini dilakukan dengan teknik purposive sampling, agar data yang diperoleh dari informan sesuai dengan kebutuhan dan tujuan penelitian (Arifin, 2011: 221). Selanjutnya data yang diperoleh dalam penelitian ini dianalisis menurut jenis data dan teknik analisis yang sesuai untuk menjawab pertanyaan penelitian.

Data yang diperoleh dalam penelitian ini dianalisis menurut jenis data dan teknik analisis yang sesuai untuk menjawab pertanyaan penelitian.

\section{a. Pengamatan/observasi}

Terdapat beberapa alasan mengapa pengamatan atau observasi dalam penelitian kualitatif dapat dimanfaatkan sebesarbesarnya. Pengamatan atau observasi adalah instrumen lain yang sering dijumpai dalam penelitian pendidikan. Dalam pengamatan ini peneliti lebih banyak menggunakan salah satu panca indranya yaitu indra penglihatan. Instrumen pengamatan akan lebih efektif jika informasi yang hendak diambil berupa fakta fakta alami, tingkah laku dan hasil kerja responden dalam situasialami. Seperti dikemukakan oleh Sugiyono (2009: 310) bahwa melalui pengamatan, peneliti belajar tentang perilaku, dan makna dari perilaku tersebut.

b. Dokumentasi

Mantja (2008: 68) mengatakan bahwa pada penelitian kualitatif sebagian besar data diperoleh dari sumber manusia melalui teknik utama pengamatan berperanserta yang dikenal dengan metode interaktif, tetapi data dapat juga diperoleh dari sumber data bukan manusia yang biasanya berupa dokumen yang bersifat noninteraktif. Pada teknik ini, peneliti dimungkinkan memperoleh informasi dari bermacam-macam sumber tertulis atau dokumen yang ada. Menurut Moleong (2005: 161) dokumen sudah lama digunakan dalam 
penelitian sebagai sumber data, karena dalam banyak hal dokumen sebagai sumber data dapat dimanfaatkan untuk menguji, menafsir, bahkan untuk meramalkan. Darmadi (2011: 266) mengatakan bahwa sumber dokumen yang ada pada umumnya dapat dibedakan menjadi dua macam dokumen yaitu dokumen resmi, termasuk surat keputusan, surat instruksi, dan surat bukti kegiatan yang dikeluarkan dari kantor atau organisasi yang bersangkutan

Analisis data adalah proses mencari dan menyusun secara sistematis data yang diperoleh dari catatan lapangan, dan dokumentasi, dengan mengorganisasikan data ke dalam kategori, menjabarkan ke dalam unit-unit, melakukan sintesa, menyusun de dalam pola, memilih mana yang penting dan yang akan dipelajari, dan membuat kesimpulan sehingga mudah difahami oleh diri sendiri maupun orang lain (Moleong, 1993: 190).

Moleong juga menambahkan adapun langkah-langkah yang dibentuk adalah dengan menelaah seluruh data yang tersedia dari berbagai sumber, setelah dibaca, dipelajari dan ditelaah kemudian mengadakan reduksi yang dilakukan dengan jalan membuat abstraksi, dan selanjutnya adalah menyusunnya dalam satuan-satuan. Sehubungan dengan hal tersebut di atas dalam menganalisis hasil temuan ini menggunakan tiga macam analisis yaitu reduksi data, display (penyajian data), dan verifikasi data atau kesimpulan.

Dalam penelitian ini, yang menjadi pokok permasalahan adalah bagaimana evaluasi pembelajaran untuk mata kuliah bahasa Inggris II jika dilihat dari perspektif sistem pembelajaran. Hal ini dilakukan karena tujuan diadakannya penelitian ini adalah untuk mencari keefektifan sistem pembelajaran. Hasil yang didapatkan diharapkan bisa digunakan untuk peningkatan yang lebih baik dan juga digunakan sebagai dasar dalam pembuatan silabi dan SAP mata kuliah bahasa Inggris II pada pogram studi baru di jurusan Tarbiyah yaitu program studi Pendidikan Guru Madrasah Ibtidaiyah (PGMI) dan juga program studi Pendidikan Guru Raudlatul Athfal (PGRA) pada khususnya dan program studi baru jurusan lainnya di STAIN Kudus. 
Syaiful Mujab

\section{B. Pembahasan}

\section{Evaluasi}

Evaluasi berasal dari kata evaluation (bahasa Inggris). Kata tersebut diserap ke dalam perbendaharaan istilah bahasa Indonesia dengan tujuan mempertahankan kata aslinya dengan sedikit penyesuaian lafal Indonesia menjadi "evaluasi". Istilah "penilaian" merupakan kata benda dari "nilai". Pengertian "pengukuran" mengacu pada kegiatan membandingkan sesuatu hal dengan satuan ukuran tertentu, sehingga sifatnya menjadi kuantitatif. Menurut Arikunto (2010: 2) mendefinisikan evaluasi adalah kegiatan untuk mengumpulkan informasi tentang bekerjanya sesuatu, yang selanjutnya informasi tersebut digunakan untuk menentukan alternatif yang tepat dalam mengambil sebuah keputusan.

Sedangkan Arifin (2012: 2) menyatakan bahwa ada beberapa istilah yang sering disalahartikan dan disalahgunakan dalam praktik evaluasi, yaitu tes, pengukuran, penilaian dan evaluasi. Secara konsepsional istilah-istilah tersebut berbeda satu sama lain, tetapi mempunyai hubungan yang sangat erat. Istilah "tes" berasal dari bahasa latin "testum" yang berarti sebuah piring atau jambangan dari tanah liat. Istilah tes ini kemudian dipergunakan dalam lapangan psikologi, yaitu suatu cara untuk menyelidiki seseorang. Sedangkan istilah pengukuran adalah suatu proses atau kegiatan untuk menentukan kuantitas sesuatu. Kata"sesuatu” bisa berarti peserta didik, pendidik, sekolah, dan sebagainya. Dalam proses pengukuran, tentu seorang pendidik harus menggunakan alat ukur baik berupa tes atau pun non tes. Alat ukur tersebut harus sesuai dengan standar, yaitu memiliki derajat validitas dan reliabilitas yang tinggi.

Wujud dari hasil evaluasi adalah adanya rekomendasi dari evaluator untuk pengambil keputusan (decision maker). Menurut Arikunto dan Safruddin (2008: 22) ada empat kemungkinan kebijakan yang dapat dilakukan berdasarkan hasil evaluasi pelaksanaan program, yaitu: (1) menghentikan program, karena dipandang bahwa program tersebut tidak ada manfaatnya, atau tidak dapat terlaksana sebagaimana yang diharapkan; (2) merevisi program, karena ada bagian-bagian yang kurang sesuai dengan harapan (terdapat kesalahan tetapi sedikit); (3) melanjutkan 
program, karena pelaksanaan program menunjukkan bahwa segala sesuatu sudah berjalan sesuai dengan harapan dan memberikan hasil yang bermanfaat; dan (4) menyebarkan program (melaksanakan program di tempat lain atau mengulangi lagi program di lain waktu), karena program tersebut berhasil dengan baik, maka sangat baik jika dilaksanakan lagi di tempat dan waktu lain.

Dalam bidang pendidikan ditinjau dari sasarannya, evaluasi ada yang bersifat makro dan ada yang mikro. Evaluasi yang bersifat makro sasarannya adalah program pendidikan, yaitu program yang direncanakan untuk memperbaiki bidang pendidikan. Evaluasi mikro sering digunakan di tingkat kelas. Jadi sasaran evaluasi mikro adalah program pembelajaran di kelas dan yang menjadi penanggung jawabnya adalah guru untuk sekolah atau dosen untuk perguruan tinggi (Mardapi, 2000: 2). Guru mempunyai tanggung jawab menyusun dan melaksanakan program pembelajaran di kelas, sedangkan pimpinan sekolah bertanggung jawab untuk mengevaluasi program pembelajaran yang disusun dan dilaksanakan oleh guru.

Istilah penilaian berarti bahwa suatu proses atau kegiatan yang sistematis dan berkesinambungan untuk mengumpulkan informasi tentang proses dan hasil belajar peserta didik dalam rangka membuat keputusan-keputusan berdasarkan kriteria dan pertimbangan tertentu. Keputusan yang dimaksud adalah keputusan tentang peserta didik, seperti nilai yang akan diberikan atau juga tentang kelulusan. Sedangkan istilah evaluasi merupakan suatu proses yang sistematis dan berkelanjutan untuk menentukan kualitas (nilai dan arti) dari sesuatu berdasarkan pertimbangan dan kriteria tertentu dalam rangka pembuatan keputusan.

\section{Pembelajaran}

Pembelajaran berasal dari kata dasar "belajar". Dalam arti sempit pembelajaran dapat diartikan sebagai suatu proses atau cara yang dilakukan agar seseorang dapat melakukan kegiatan belajar, sedangkan belajar adalah suatu proses perubahan tingkah laku karena interaksi individu dengan lingkungan dan pengalaman. Arifin (2012: 10) lebih menekankan bahwa pembelajaran merupakan kegiatan belajar peserta didik secara sungguh-sungguh yang melibatkan aspek intelektual, emosional, dan sosial. Dia menambahkan bahwa 
arti pembelajaran secara luas adalah suatu proses atau kegiatan yang sistematis dan sistemik, yang bersifat interaktif dan komunikatif antara pendidik dengan peserta didik, sumber belajar dan lingkungan untuk menciptakan suatu kondisi yang memungkinkan terjadinya tindakan belajar peserta didik, baik di kelas maupun di luar kelas, dihadiri guru secara fisik atau tidak, untuk menguasai kompetensi yang telah ditentukan.

Menurut aliran behavioristik, pembelajaran adalah usaha pendidik dalam membentuk tingkah laku yang diinginkan dengan menyediakan lingkungan atau stimulus. Aliran kognitif mendefinisikan pembelajaran sebagai cara guru memberikan kesempatan kepada peserta didik untuk berfikir agar mengenal dan memahami sesuatu yang sedang dipelajari Sedangkan aliran humanistik mendiskripsikan pembelajaran sebagai memberikan kebebasan kepada peserta didik untuk memilih bahan pelajaran dan cara mempelajarinya sesuai dengan minat dan kemampuannya (Sugandi, 2004: 9).

Dari beberapa pengertian pembelajaran tersebut, dapat disimpulkan bahwa inti dari pembelajaran itu adalah segala upaya yang dilakukan oleh guru (pendidik) agar terjadi proses belajar pada diri siswa. Secara implisit, di dalam pembelajaran, ada kegiatan memilih, menetapkan dan mengembangkan metode untuk mencapai hasil pembelajaran yang diinginkan. Pembelajaran lebih menekankan pada cara-cara untuk mencapai tujuan dan berkaitan dengan bagaimana cara mengorganisasikan materi pelajaran, menyampaikan materi pelajaran, dan mengelola pembelajaran.

Darsono yang dikutip oleh Hamdani (2011: 47) menyatakan behwa ciri-ciri pembelajaran adalah sebagai berikut:

1. Pembelajaran dilakukan secara sadar dan direncanakan secara sistematis.

2 Pembelajaran dapat menumbuhkan perhatian dan motivasi siswa dalam belajar

3. Pembelajaran dapat menyediakan bahan belajar yang menarik perhatian dan menantang siswa.

4. Pembelajaran dapat menggunakan alat bantu belajar yang tepat dan menarik

5. Pembelajaran dapat menciptakan suasana belajar yang aman dan menyenangkan bagi peserta didik. 
6. Pembelajaran dapat membuat peserta didik siap menerima pelajaran, baik secara fisik maupun psikologis.

7. Pembelajaran menekankan keaktifan peserta didik

8. Pembelajaran dilakukan secara sadar dan sengaja.

Dari ciri-ciri pembelajaran tersebut diatas dapat diketahui bahwa pembelajaran pasti mempunyai tujuan yaitu membantu siswa agar memperoleh berbagai pengalaman dan dengan pegalaman itu, tingkah laku peserta didik bertambah, baik kuantitas maupun kualitasnya. Tingkah laku ini meliputi pengetahuan, keterampilan, dan nilai atau norma yang berfungsi sebagai pengendali sikap dan perilaku peserta didik.

Dalam proses pembelajaran, kedudukan guru sudah tidak lagi dipandang sebagai penguasa tunggal, tetapi dianggap sebagai manager oflearning (pengelola belajar) yang perlu senantiasa siap membimbing dan membantu para siswa. Dalam proses pembelajaran, telah mengubah peran guru dan siswa. Peran guru telah berubah dari: (1) sebagai penyampai pengetahuan, sumber utama informasi, ahli materi dan sumber segala jawaban, menjadi sebagai fasilitator pembelajaran, pelatih, kolabolator, dan mitra belajar; (2) dari mengendalikan dan mengarahkan semua aspek pembelajaran, menjadi lebih banyak memberikan alternatif dan tanggung jawab kepada setiap siswa dalam proses pembelajaran. Sementara itu peran siswa dalam pembelajaran telah mengalami perubahan juga, yaitu: (1) dari penerima informasi yang pasif menjadi partisipan aktif dalam proses pembelajaran, (2) dari mengungkapkan kembali pengetahuan menjadi menghasilkan dan berbagi pengetahuan, (3) dari pembelajaran sebagai aktivitas individual menjadi pembelajaran berkolaboratif dengan siswa lain.

\section{Tujuan dan Fungsi Evaluasi Pembelajaran}

Dalam setiap kegiatan evaluasi, langkah pertama yang harus diperhatikan adalah mengetahui tujuan evaluasi. Penentuan tujuan evaluasi sangat bergantung pada jenis evaluasi yang digunakan. Apabila kita ingin melakukan kegiatan evaluasi, terlepas dari jenis evaluasi apa yang digunakan, maka seorang pendidik harus mengetahui terlebih dahulu tentang tujuan dan fungsi evaluasi. Bila tidak maka pendidik akan mengalami kesulitan merencanakan dan melaksanakan evaluasi. Oleh karena itu, tujuan evaluasi 
pembelajaran adalah untuk mengetahui keefektifan dan efisiensi sistem pembelajaran, baik yang menyangkut tentang tujuan, materi, metode, media, sumber belajar, lingkungan maupun sistem penilaian itu sendiri. Tujuan khusus evaluasi pembelajaran disesuaikan dengan jenis evaluasi pembelajaran itu sendiri seperti evaluasi perencanaan dan pengembangan, evaluasi monitoring, evaluasi dampak, evaluasi efisiensi-ekonomis, dan evaluasi program komprehensif. Adapun fungsi evaluasi memang cukup luas bergantung dari sudut pandang mana kita melihatnya. Fungsi evaluasi menurut Arifin (2012: 16) diantaranya adalah:

1. Secara psikologis, dalam hal ini peserta didik selalu butuh untuk mengetahui sejauh mana kegiatan yang telah dilakukan sesuai dengan tujuan yang hendak dicapai. Peserta didik adalah manusia yang belum dewasa. Mereka masih mempunyai sikap dan moral yang heteronom, membutuhkan pendapat orang-orang dewasa (seperti orang tua dan guru) sebagai pedoman baginya untuk mengadakan orientasi pada situasi tertentu. Dalam menentukan sikap dan tingkah lakunya, mereka pada umumnya tidak berpegang kepada pedoman yang berasal dari dalam dirinya sendiri, melainkan mengacu kepada norma-norma yang berasal dari luar dirinya. Dalam pembelajaran, mereka perlu mengetahui prestasi belajarnya sehingga ia merasakan kepuasan dan ketenangan. Untuk itu, seorang pendidik perlu melakukan evaluasi pembelajaran, termasuk penilaian prestasi belajar peserta didik.

2. Secara sosiologis, evaluasi berfungsi untuk mengetahui apakah peserta didik sudah cukup mampu untuk terjun ke masyarakat. Mampu disini dalam arti bahwa peserta didik dapat berkomunikasi dan beradaptasi terhadap seluruh lapisan masyarakat dengan segala karakteristiknya. Lebih jauh dari itu diharapkan peserta didik dapat membina dan mengembangkan semua potensi yang ada dalam masyarakat. Hal ini penting karena mampu tidaknya pesert didik terjun ke masyarakat akan memberikan ukuran tersendiri terhadap institusi pendidikan yang bersangkutan. Implikasinya adalah bahwa kurikulum dan pembelajaran harus sesuai dengan kebutuhan masyarakat. 
3. Secara Didaktis-metodis, evaluasi berfungsi untuk membantu pendidik dalam menempatkan peserta didik pada kelompok tertentu sesuai dengan kemampuan dan kecakapannya masing-masing serta membantu pendidik dalam usaha memperbaiki proses pembelajarannya

4. Evaluasi berfungsi untuk mengetahui kedudukan peserta didik dalam kelompok, apakah dia termasuk anak yang pandai, sedang, atau kurang pandai. Hal ini berhubungan dengan sikap dan tanggung jawab orang tua sebagai pendidik pertama dan utama di lingkungan keluarga. Orang tua perlu mengetahui kemajuan anak-anaknya untuk menentukan langkah-langkah selanjutnya.

5. Evaluasi berfungsi untuk mengetahui taraf kesiapan peserta didik dalam menempuh program pendidikannya. Jika peserta didik sudah dianggap siap (fisik dan non-fisik), maka program pendidikan dapat dilaksanakan. Sebaliknya, jika peserta didik belum siap, maka hendaknya program pendidikan tersebut jangan dulu diberikan, karena akan mengakibatkan hasil yang kurang memuaskan.

6. Evaluasi berfungsi membantu pendidik dalam memberikan bimbingan dan seleksi, baik dalam rangka menentukan jenis pendidikan, jurusan, maupun kenaikan kelas. Melalui evaluasi kita dapat mengetahui potensi peserta didik sehingga kita pun dapat memberikan bimbingan sesuai dengan tujuan yang diharapkan. Begitu juga tentang kenaikan kelas atau kelulusan. Jika peserta didik belum menguasai kompetensi yang ditentukan, maka peserta didik tersebut jangan diluluskan atau dinaikkan ke kelas berikutnya atau yang lebih tinggi. Kegagalan ini merupakan hasil keputusan evaluasi, karena itu pendidik perlu mengadakan bimbingan yang lebih profesional.

7. Secara administratif, evaluasi berfungsi untuk memberikan laporan tentang kemajuan peserta didik kepada orang tua, pejabat pemerintah yang berwenang, kepala sekolah, guruguru, dan peserta didik itu sendiri. Hasil evaluasi dapat memberikan gambaran secara umum tentang semua hasil usahayang dilakukan oleh institusi pendidikan. 
Syaiful Mujab

\section{Ruang Lingkup Evaluasi}

Adapun ruang lingkup evaluasi berkaitan dengan cakupan objek evaluasi itu sendiri. Jika objek evaluasi itu tentang pembelajaran, maka semua hal yang berkaitan dengan pembelajaran menjadi ruang lingkup evaluasi pembelajaran. Ruang lingkup evaluasi pembelajaran hendaknya bertitik tolak dari tujuan evaluasi pembelajaran itu sendiri. Jika tujuan evaluasi adalah untuk mengetahui keefektifan sistem pembelajaran, ruang lingkup evaluasi pembelajaran adalah sebagai berikut.

a. Program pembelajaran, yang meliputi:

1) Tujuan pembelajaran umum atau kompetensi dasar

Yaitu target yang harus dikuasai peserta didik dalam setiap pokok bahasan atau topik. Kriteria yang digunakan untuk mengevaluasi tujuan pembelajaran umum atau kompetensi dasar ini adalah berkaitannya dengan tujuan kurikuler atau standar kompetensi dari setiap bidang studi atau mata pelajaran dan tujuan kelembagaan, kejelasan rumusan kompetensi dasar, kesesuaiannya dengan tingkat perkembangan peserta didik, pengembangannya dalam bentuk hasil belajar dan indikator, penggunaan kata kerja operasional dalam indikator, dan unsur-unsur penting dalam kompetensi dasar, hasil belajar, dan indikator.

2) Isi atau materi pembelajaran

Yaitu isi kurikulum yang berupa topik atau pokok bahasan dan subtopik/subpokokbahasan beserta perinciannya dalam setiap bidang studi atau mata pelajaran. Isi kurikulum tersebut memiliki tiga unsur, yaitu logika (pengetahuan benar salah, berdasarkan prosedur keilmuan), etika (baikburuk), dan estetika (keindahan). Materi pembelajaran dapat dikelompokkan menjadi enam jenis, yaitu fakta, konsep/ teori, prinsip, proses, nilai dan ketrampilan. Kriteria yang digunakan antara lain kesesuaiannya dengan kompetensi dasar dan hasil belajar, ruang lingkup materi, urutan logis materi, kesesuaiannya dengan tingkat perkembangan dan kebutuhan peserta didik, waktu yang tersedia dan sebagainya.

3) Metode pembelajaran 
Yaitu cara seorang pendidik menyampaikan materi pelajaran, seperti metode ceramah, tanya jawab, diskusi, pemecahan masalah, dan sebagainya. Kriteria yang digunakan antara lain kesesuaiannya dengan kompetensi dasar dan hasil belajar, kesesuaiannya dengan kondisi kelas/sekolah, kesesuaiannya dengan tingkat perkembangan peserta didik, kemampuan pendidik dalam menggunakan metode, dan waktu yang tersedia.

4) Media pembelajaran

Yaitu alat-alat yang membantu untuk mempermudah pendidik dalam menyampaikan isi/materi pelajaran. Media dapat dibagi tiga kelompok, yaitu media audio, media visual, dan media audio-visual. Kriteria yang digunakan sama seperti komponen metode.

5) Sumber belajar

Sumber belajar meliputi pesan, orang, bahan, alat, teknik, dan latar. Sumber belajar dapat dibedakan menjadi dua jenis yaitu sumber belajar yang dirancang (resources by design) dan sumber belajar yang digunakan (resources by utilization). Kriteria yang digunakan sama seperti komponen metode.

6) Lingkungan,

Hal ini terutama lingkungan sekolah dan lingkungan keluarga. Kriteria yang digunakan antara lain hubungan antara peserta didik dan teman sekelas/sekolah maupun di luar sekolah, pendidik dan orang tua, serta kondisi keluarga.

7) Penilaian proses dan hasil belajar, baik yang menggunakan tes maupun non tes. Kriteria yang digunakan antara lain kesesuaiannya dengan kompetensi dasar, hasil belajar, dan indikator kesesuaiannya dengan tujuan dan fungsi penilaian, unsur-unsur penting dalam penilaian, aspek-aspek yang dinilai, kesesuaiannya dengan tingkat perkembangan peserta didik, jenis dan alat penilaian.

\section{Proses Pelaksanaan Pembelajaran}

Proses pelaksanaan pembelajaran, meliputi:

1) Kegiatan, yang meliputi jenis kegiatan, prosedur pelaksanaan 
setiap jenis kegiatan, sarana pendukung, efektivitas dan efisiensi, dan sebagainya.

2) Pendidik, terutama dalam hal menyampaikan materi, kesulitan-kesulitan pendidik, menciptakan suasana pembelajaran yang kondusif, menyiapkan alat-alat dan perlengkapan yang diperlukan, membimbing peserta didik, menggunakan teknik penilaian, menerapkan disiplin kelas, dan sebagainya.

3) Peserta didik, terutama dalam hal peran serta peserta didik dalam kegiatan belajar dan bimbingan, memahami jenis kegiatan, mengerjakan tugas-tugas, perhatian, keaktifan, motivasi, sikap, minat, umpan balik, kesempatan melaksanakan praktik dalam situasi yang nyata, kesulitan belajar, waktu belajar, istirahat, dan sebagainya

4) Hasil pembelajaran, baik untuk jangka pendek (sesuai dengan pencapaian indikator), jangka menengah (sesuai dengan target untuk setiap bidang studi/mata pelajaran), dan jangka panjang (setelah peserta didik terjun ke masyarakat)

Adapun hasil dari penelitian ini adalah sebagai berikut.

a. Dilihat dari Program Pembelajarannya

Setelah dievaluasi, Mata kuliah Bahasa Inggris II (Reading) dilihat dari program pembelajarannnya maka secara keseluruhan dapat disimpulkan bahwa pembelajaran mata kuliah bahasa Inggris di jurusan Tarbiyah Sekolah Tinggi Agama Islam (STAIN) Kudus sudah berjalan dengan baik. Hal ini terbukti bahwa pada setiap unsur pembelajaran mata kuliah bahasa Inggris sudah dilaksanakan sesuai dengan ketentuan indikator yang sudah ditetapkan. Adapun penjelasan tiap-tiap unsur adalah:

1) Tujuan Pembelajaran Umum atau Kompetensi dasar.

Menurut Arifin (2012: 24) menyatakan bahwa:

"Tujuan pembelajaran umum atau kompetensi dasar, yaitu target yang harus dikuasai peserta didik dalam setiap pokok bahasan/topik. Kriteria yang digunakan untuk mengevaluasi tujuan pembelajaran umum atau kompetensi dasar ini adalah berkaitannya dengan tujuan kurikuler atau standar kompetensi dari setiap bidang studi atau mata pelajaran dan tujuan kelembagaan, kejelasan rumusan kompetensi dasar, kesesuaiannya dengan tingkat perkembangan peserta didik, pengembangannya dalam bentuk hasil belajar dan indikator, penggunaan kata kerja operasional 
dalam indikator, dan unsur-unsur penting dalam kompetensi dasar, hasil belajar, dan indikator."

Dilihat dari silabus mata kuliah bahasa Inggris maka apa yang menjadi kriteria evaluasi tujuan pembelajaran sudah berkaitan dengan standar kompetensi. Hal ini tercantum didalam silabus yang menyatakan bahwa standar kompetensi mata kuliah bahasa Inggris adalah mahasiswa mempunyai ketrampilan dalam memahami isi teks berbahasa Inggris baik secara global maupun detil, khususnya yang terkait dengan literature keIslaman. Sedangkan kompetensi dasar mata kuliah bahasa Inggris berbunyi:

1. Mahasiswa mampu memahami dan menterjemahkan text bahasa Inggris tentang Islam

2. Mahasiswa mampu memahami dan menterjemahkan text bahasa Inggris tentang Pendidikan

Teksyangdiambilsebagaibahanajarperkuliahandiambilkan dari teks-teks berbahasa Inggris dengan menggunakan literatur keIslaman. Teks itu diambilkan dari buku karangan Djamaluddin Darwis dengan judul English for Islamic Studies. Adapun teks bacaan yang dipilih sebagai bahan ajar juga sesuai dengan perkembangan peserta didik khususnya mahasiswa STAIN Kudus.

2) Isi / Materi Pembelajaran

Berdasarkan ruang lingkup isi/materi pembelajaran mata kuliah bahasa Inggris II di jurusan Tarbiyah STAIN Kudus sudah sesuai dengan kompetensi dasar dan hasil belajar. Selain itu juga ruang lingkup materi sudah logis dan sesuai dengan perkembangan dan kebutuhan peserta didik. Sedangkan waktu yang digunakan dalam pembelajaran sudah cukup untuk proses kegiatan belajar mengajar. Hal ini dikarenakan mata kuliah bahasa Inggris di STAIN Kudus tidak hanya bahasa Inggris II tetapi juga ada mata kuliah bahasa Inggris I dan praktikum bahasa Inggris. Dengan pembahasan focus yang berbeda membekali mahasiswa terampil dalam berbahasa Inggris karena 4 komponen keterampilan berbahasa dapat diberikan kepada mahasiswa STAIN Kudus. 
Adapun teks bacaan yang menjadi topik/pokok bahasan dalam bahasa Inggris II adalah sebagai berikut:

1. Reading : Prophet Muhammad (1)

2. Reading : Allah - the God sesuai

3. Reading : Faith

4. Reading : Islam

5. Reading : The Sources of Islam

6. Reading : The Qur'an

7. Reading : Books of Allah

8. Reading : The Prophet

9. Reading : The Angels

10. Reading : Life after Death

11. Reading : The Black Stone of Kaaba

12. Reading : Performing the Fifth Pillar of Islam :The Haj

13. Reading : A University Life

14. Reading : To Learn a Foreign Language

3) Metode Pembelajaran

Menurut Arifin (2012: 24) menyatakan bahwa

"Metode pembelajaran Yaitu cara seorang pendidik menyampaikan materi pelajaran, seperti metode ceramah, tanya jawab, diskusi, pemecahan masalah, dan sebagainya. Kriteria yang digunakan antara lain kesesuaiannya dengan kompetensi dasar dan hasil belajar, kesesuaiannya dengan kondisi kelas/sekolah, kesesuaiannya dengan tingkat perkembangan peserta didik, kemampuan pendidik dalam menggunakan metode, dan waktu yang tersedia."

Berdasarkan uraian diatas, maka metode pembelajaran yang digunakan dalam mengajar mata kuliah bahasa Inggris II selama ini sudah sesuai dengan kompetensi dasar dan hasil belajar. Hal ini terbukti dari metode yang digunakan dalam pembelajaran bahasa Inggris II yaitu dengan lecturing, reading aloud, reading guide untuk mendapatkan atau mencari informasi tentang isi bacaan. Setelah itu menggunakan metode diskusi untuk mendapatkan wawasan kosakata baru. Penggunaan pemilihan metode pembelajaran sesuai dengan kondisi kelas/sekolah dan tingkat perkembangan peserta didik sehingga memberikan motivasi kepada peserta didik untuk belajar bahasa Inggris. 
4) Media Pembelajaran

Dalam meningkatkan pembelajaran bahasa Inggris, dosen menggunakan media Laptop, LCD, dan sound system dalam penyampaian materi bahasa Inggris yang sudah disediakan di ruang perkuliahan. Hal ini bisa membangkitkan atau memotivasi peserta didik untuk lebih giat belajar.

5) Sumber Belajar

Dalam pembelajaran bahasa Inggris menggunakan sumber belajar buku yang sudah disediakan di perpustakaan STAIN Kudus. Hal ini akan mempermudah mahasiswa STAIN Kudus untuk mencari bahan referensi guna lebih meningkatkan wawasan dan pengetahuan mereka. Setiap mahasiswa STAIN kudus mendapatkan kartu anggota perpustakaan terhitung sejak mengikuti pelatihan perpustakaan sebagai syarat menjadi mahasiswa baru sampai dengan mereka lulus kuliah. Dengan pelatihan perpustakaan akan mempermudah mahasiswa dalam mencari buku referensi yang diinginkannya. Buku pegangan yang mendukung pembelajaran bahasa Inggris untuk bisa dipinjam misalnya buku karangannya Djamaluddin Darwis dengan judul bukunya English for Islamic Studies dan buku karangannya Betty Azar dalam bukunya Understanding and Using English Grammar.

Sumber belajar lainnya yang disediakan oleh STAIN Kudus dalam meningkatkan pembelajaran bahasa Inggris II adalah disediakannya "HOT SPOT AREA" di lingkungan STAIN Kudus. Hal ini sangat mendukung mahasiswa untuk bisa mendownload materi / bacaan berbahasa Inggris atau juga melakukan pembelajaran bahasa Inggris melalui e-learning yang sudah disepakati antara dosen dan mahasiswa. Selain itu, dengan adanya fasilitas Hot Spot Area menjadikan mahasiswa STAIN kudus tidak dikatakan "gatek" alias "gagap teknologi".

6) Lingkungan

Apabila di lihat dari lingkungan, terutama lingkungan sekolah dan lingkungan keluarga, maka bisa dikatakan bahwa 
hubungan antara peserta didik dan teman sekelas/ sekolah berjalan dengan baik. Hal ini terlihat dari keaktifan mahasiswa yang ikut kegiatan organisasi yang diselenggarakan di kampus STAIN Kudus. Dengan aktifnya mereka berorganisasi membuktikan bahwa mereka tidak hanya dekat dengan teman sekelasnya saja tetapi mereka dapat membaur dengan teman di luar kelasnya ketika mereka berorganisasi di kampus STAIN Kudus.

Hubungan antara pendidik dan peserta didik dalam hal ini antara dosen dengan mahasiswa terlihat adanya hubungan yang baik. Keeratan hubungan ini terlihat bahwa ketika UKM bahasa Inggris menyelenggarakan lomba pidato berbahasa Inggris tingkat SMA sederajat se-karesidenan Pati, mahasiswa meminta dosen bahasa Inggris sebagai salah satu jurinya. Hal ini menandakan bahwa lingkungan kampus mendukung adanya pembelajaran bahasa Inggris.

Bagi mahasiswa yang dari keluarga kurang mampu maka disediakan beasiswa untuk medukung proses perkuliahan mereka. Hal ini berarti hubungan antara peserta didik, dosen dan orang tua sangat baik.

7) Penilaian Proses dan Hasil Belajar

Unsurterakhirdaripembelajaranadalahpenilaianprosesdan hasil belajar. Hal ini bisa ditunjukkan setiap semester minimal mengadakan penilaian tengah semester dan penilaian akhir semester.

b. Dilihat dari Proses Pelaksanaan Pembelajaran

Berdasarkan proses pelaksanaan pembelajaran ada 3 unsur yang saling berkaitan. Tiga unsur itu adalah adanya suatu kegiatan pembelajaran harus ada pendidik dalam hal ini dosen mata kuliah tersebut dan peserta didik yaitu mahasiswa yang mengikuti kegiatan perkuliahan. Kegiatan pekuliahan untuk mata kuliah bahasa Inggris II di jurusan Tarbiyah dilaksanakan di setiap semester Genap. Dalam setiap semester terdiri dari 16 kali pertemuan, dengan rincian 14 kali pertemuan digunakan untuk tatap muka dikelas dan 1 kali pertemuan untuk ujian tengah semester, dan 1 kali pertemuan lagi digunakan untuk ujian akhir semester. Pelaksanaan ujian Mid-term test (tengah 
semester) dilaksanakan pada pertemuan ke 8 dan pelaksanaan ujian akhir semester pada pertemuan ke 16 .

Pada pertemuan pertama, biasanya digunakan oleh dosen untuk perkenalan dan kesepakatan kontrak perkuliahan. Dalam kontrak perkuliahan tersebut membuat persetujuan antara dosen dan peserta didik mulai dari kesepakatan masuk perkuliahan sampai dengan prosedur penilaian mata kuliah bahasa Inggris. Mata kuliah bahasa Inggris hanya 2 SKS, yang artinya bahwa waktu perkuliahan hanya selama 100 menit. Di STAIN Kudus aturan lamanya per 1 SKS adalah 50 menit.

Setiap awal masuk perkuliahan dosen bahasa Inggris sudah mendapatkan stopmap yang berisi daftar nama-nama mahasiswa di setiap kelasnya. Untuk setiap kelas, jurusan tarbiyah masingmasing berisi sekitar 37 mahasiswa putra dan putri. Jurusan Tarbiyah merupakan jurusan yang menjadi pilihan prioritas bagi mahasiswa. Hal ini dikarenakan masyarakat pada umumnya berfikir bahwa jurusan tarbiyah (Pendidikan Agama) lebih mudah mendapatkan tempat di masyarakat dibandingkan dengan jurusan yang lainnya. Seperti halnya, peluang untuk bisa masuk Calon Pegawai Negeri Sipil adalah dari bidang pendidikan. Selain stopmap, perlengkapan menulis seperti broadmaker langsung diberikan kepada dosen oleh tenaga kependidikan jurusan Tarbiyah. Sedangkan penghapus, dan LCD sudah disediakan di masing-masing ruangan kelas.

Dalam menunjang kemampuan bahasa Inggris, dosen memberikan tugas kepada mahasiswa untuk dikerjakan baik secara individual ataupun secara kelompok. Tugas itu diberikan sesuai dengan tema/topik yang dibicarakan, misalnya dalam mata kuliah bahasa Inggris II, mahasiswa diberi tugas untuk menerjemahkan teks berbahasa Inggris. Dengan pemberian tugas tersebut bisa menambah kekayaan vocabulary (kosakata) sehingga menambah bekal mahasiswa untuk bisa berkomunikasi dengan menggunakan bahasa Inggris. Dalam setiap pertemuan apa yang dibahas di kelas telah dirancang dalam Satuan Acara Perkuliahan yang disingkat dengan SAP.

c. Dilihat dari Hasil Pembelajaran

Hasil pembelajaran, mata kuliah bahasa Inggris baik untuk jangka pendek, jangka menengah, dan jangka panjang sudah sesuai 
dengan target indikator yang harus dicapai. Dalam jangka pendek, hasil evaluasi pembelajaran mata kuliah bahasa Inggris terlihat bagus. Hal ini dilihat dari hasil nilai tugas yang telah dikerjakan oleh mahasiswa. Sedangkan dalam jangka menengah, hasil evaluasi pembelajaran mata kuliah bahasa Inggris dilihat dari nilai ujian tengah semester. Dari hasil tersebut bisa dilihat nilai ujian tengah semester mahasiswa bagus. Apabila hasil ujian akhir semester bagus atau dinyatakan lulus, mengandung arti bahwa mahasiswa siap untuk diterjunkan ke masyarakat untuk berkomunikasi dengan menggunakan bahasa Inggris. Semua nilai tersebut ditulis di dalam daftar nilai ujian.

1. Tawaran Mata Kuliah Bahasa Inggris II untuk Pogram Studi Pendidikan Guru Madrasah Ibtidaiyah (PGMI) dan Pendidikan Guru Raudlatul Athfal (PGRA)

a) Mata Kuliah Bahasa Inggris di STAIN Kudus

Mata kuliah bahasa Inggris di Sekolah Tinggi Agama Islam Negeri Kudus merupakan mata kuliah wajib diikuti oleh semua mahasiswa. Hal ini dilaksanakan berdasarkan ketentuan Undang-undang No 20 tahun 2003 tentang Pendidikan Nasional, Pasal 33 ayat (3) yang menyatakan bahasa asing dapat digunakan sebagai bahasa pengantar pada satuan pendidikan tertentu untuk mendukung kemampuan berbahasa asing peserta didik. Mata kuliah bahasa Inggris di dalam kurikulum di setiap jurusan di STAIN Kudus dibagi menjadi dua, diantaranya adalah bahasa Inggris I dan bahasa Inggris II. Berdasarkan kesepakatan dosen-dosen bahasa Inggris STAIN Kudus menetapkan bahwa bahasa Inggris I lebih difokuskan pada tata bahasa (grammar) untuk mendukung keterampilan menulis (writing), sedangkan untuk mata kuliah bahasa Inggris II difokuskan pada keterampilan membaca (reading). Selain itu, di dalam kurikulum juga ditawarkan mata kuliah praktikum bahasa Inggris. Dengan adanya praktikum bahasa Inggris yang lebih difokuskan pada keterampilan berbicara (speaking) dan mendengarkan (listening) diharapkan cukup menjadi bekal mahasiswa untuk menguasai bahasa Inggris karena mereka berarti sudah memiliki 4 komponen keterampilan berbahasa yang menjadi 
modal untuk bisa memahami dan menguasai bahasa Inggris.

Pelaksanaan mata kuliah bahasa Inggris di setiap jurusan pada semesternya dilakukan dalam waktu yang berbeda. Untuk jurusan Syariah dan jurusan Dakwah, semua mata kuliah bahasa Inggris baik Bahasa Inggris I, Bahasa Inggris II dan praktikum Bahasa Inggris dilakukan pada semester gasal. Sedangkan mahasiswa jurusan Tarbiyah dan jurusan Ushuluddin mendapatkan semua mata kuliah bahasa Inggris, baik bahasa Inggris I, bahasa Inggris II, dan praktikum bahasa Inggris pada semester genap. Hal ini dilakukan dalam terpisah karena untuk memenuhi jumlah dosen mata kuliah bahasa Inggris yang kurang tidak sesuai dengan jumlah mahasiswa yang diterima di STAIN Kudus. Meningkatnya jumlah mahasiswa yang terlalu besar dikarenakan tuntutan dari pemerintah pusat yang mengharapkan STAIN Kudus untuk bisa menampung para generasi muda untuk lebih meningkatkan belajar pada bidang keagamaan. Hal ini seperti yang disampaikan oleh Bapak Dede Rosyada dari Kementerian Agama yang kemudian disadur kembali oleh Bapak M. Saekan Muchit selaku Wakil Ketua I bidang akademik pada rapat penerimaan mahasiswa baru STAIN Kudus yang menyatakan bahwa kita harus lebih banyak menerima mahasiswa baru untuk TA 2012/2013 karena diharapkan sekarang ini masyarakat lebih peduli dengan pendidikan keagamaan dibandingkan dengan pendidikan eksakta.

Pada Tahun Ajaran 2012/2013, STAIN Kudus melakukan terobosan-terobosan untuk membuat Program Studi baru. Alhamdulillah terobosan-terobosan yang dilakukan oleh jurusan Tarbiyah yaitu membuat program studi baru diantaranya Program Studi Pendidikan Guru Madrasah Ibtidaiyah (PGMI) dan Pendidikan Guru Raudlatul Athfal (PGRA) telah disetujui. Dengan adanya program studi baru menjadikan para civitas akademika STAIN Kudus mempunyai tugas berat untuk mensukseskan agar program studi tersebut bisa eksis dan diterima oleh masyarakat Kudus khususnya dan masyarakat sekitar Kudus pada umumnya. 
Hal yang harus dipersiapkan pertama kali adanya program studi baru adalah menentukan kurikulum yang sesuai dengan visi misi jurusan tersebut dengan tidak meninggalkan visi misi STAIN Kudus. Dalam kurikulum baik prodi PGMI ataupun prodi PGRA masing-masing menawarkan mata kuliah bahasa Inggris I, bahasa Inggris II dan praktikum bahasa Inggris seperti pada jurusan-jurusan sebelumnya.

2. Mata Kuliah Bahasa Inggris II Prodi PGMI dan PGRA

Penelitian ini merupakan penelitian pengembangan mata kuliah bahasa Inggris untuk program studi baru yaitu Pendidikan Guru Madrasah Ibtidaiyah (PGMI) dan Pendidikan Guru Raudlatul Athfal (PGRA) dengan melihat evaluasi pembelajaran bahasa Inggris pada jurusan sebelumnya. Hal ini diharapkan bisa mendapatkan hasil yang maksimal dengan meningkatkan yang sudah baik dan meninggalkan yang kurang mendukung program studi PGMI dan PGRA.

Silabi dan SAP untuk mata kuliah bahasa Inggris II pada program studi Pendidikan Guru Madrasah Ibtidaiyah (PGMI) dan Pendidikan Guru Raudlatul Athfal (PGRA) lebih difokuskan pada aplikasi penggunaan bahasa Inggris. Tawaran mata kuliah bahasa Inggris untuk program studi Pendidikan Guru Raudlatul Athfal (PGRA) sama dengan prodi PGMI. Hal ini dikarenakan objek yang mengguanakan sama yaitu masih anak-anak. Adapun rincian silabus dan SAP mata kuliah bahasa Inggris II adalah sebagai berikut:

Tawaran Mata kuliah Pembelajaran Baca, Tulis dan Hitung merupakan mata kuliah baru di STAIN kudus. Pembelajaran Seni Musik dan Seni Suara merupakan satu paduan. Dalam pembelajaran seni musik biasanya diikuti dengan pembelajaran seni suara. Seni suara lebih memfokuskan pada menyanyi karena pada pembelajaran di Raudlatul Athfal lebih ditekankan pada belajar dan bermain. Oleh karena itu di dalam kurikulum diberikan mata kuliah pembelajaran seni musik dan seni suara. 


\section{Simpulan}

Berdasarkan analisis data, dapat disimpulkan bahwa: (1) Evaluasi pembelajaran Mata Kuliah Bahasa Inggris II di jurusan Tarbiyah Sekolah Tinggi Agama Islam (STAIN) Kudus sudah berjalan dengan baik. Hal ini terbukti bahwa pada setiap unsur pembelajaran mata kuliah bahasa Inggris sudah dilaksanakan sesuai dengan ketentuan kompetensi dan indikator yang sudah ditetapkan. Berdasarkan proses pelaksanaannya, ketiga unsur yang merupakan kunci pokok terlaksananya suatu proses kegiatan belajar mengajar sudah berjalan dengan baik dan lancar. Ketiga unsur itu adalah adanya kegiatan belajar mengajar yang disampaikan oleh pendidik kepada peserta didik. Sedangkan dilihat dari hasil pembelajaran selama satu semester menunjukkan bahwa nilai mahasiswa pada mata kuliah bahasa Inggris II hasilnya tinggi. Hal ini berarti sistem pembelajaran mata kuliah Bahasa Inggris II di jurusan Tarbiyah STAIN Kudus berjalan dengan baik. (2) Implikasi dari hasil evaluasi sistem pembelajaran mata kuliah bahasa Inggris II di program studi Pendidikan Agama Islam (PAI) yang berjalan baik dapat menjadikan perbaikan dalam pembuatan tawaran silabus dan SAP mata kuliah bahasa Inggris II untuk program studi baru di jurusan Tarbiyah yaitu program studi Pendidikan Guru Madrasah Ibtidaiyah (PGMI) dan program studi Pendidikan Guru Raudlatul Athfal (PGRA). Tawaran silabus mata kuliah bahasa Inggris II untuk prodi PGMI dan PGRA agak sedikit berbeda dengan prodi PAI karena lulusan prodi baru tersebut nantinya diharapkan dapat mencetak guru bagi anak-anak usia sekitar 12 tahun kebawah. Pada usia tersebut, anak masih membutuhkan perhatian yang lebih dari guru. Oleh karena itu, pembelajaran mata kuliah bahasa Inggris II untuk prodi PGMI dan PGRA lebih difokuskan pada pengenalan kosakata terhadap benda disekitarnya.

Saran peneliti setelah melakukan penelitian ini adalah sebagai berikut: (1) Bagi program studi PAI, adanya hasil evaluasi pembelajaran dapat memberikan manfaat untuk pengembangan mutu pendidikan. (2) Bagi dosen, perlu menambah pengetahuan tentang metode pengajarannya sehingga proses belajar mengajar dapat dilaksanakan secara efektif. (3) Bagi peneliti selanjutnya sebagai acuan atau rujukan dalam melakukan penelitian selanjutnya 
Syaiful Mujab

dalam menemukan konsep pengembangan kurikulum terutama dalam pembuatan Silabus dan SAP untuk meningkatkan kualitas pendidikan dan menambah wawasan pendidikan dalam upaya mengembangkan kemampuan diri. 
Evaluasi Proses Pembelajaran Reading .....

\section{DAFTAR PUSTAKA}

Arifin, Zainal. 2012. Evaluasi Pembelajaran. Bandung: PT Remaja Rosdakarya Offset.

Arikunto, Suharsimi dan Cepi Safruddin Abdul Jabar. 2010. Evaluasi Program Pendidikan. Jakarta: PT Bumi Aksara.

Darmadi, Hamid. 2011. Metode Penelitian Pendidikan. Bandung: Alfabeta.

Depdiknas. 2006. Panduan Penilaian Kelompok Mata Pelajaran Agama dan Akhlak Mulia, Estetika, Ilmu Pengetahuan dan Teknologi, Jasmani-Olahraga dan Kesehatan. Jakarta: BSNP.

Dimyati dan Mudjiono. 1999. Belajar dan Pembelajaran. Jakarta: P3MTK-Ditjen Dikti-Depdikbud.

Furqon. 2001. Evaluasi Belajar di Sekolah, Mimbar Pendidikan No. 3 Tahun XX. Bandung: Universitas Pendidikan Indonesia.

Hamdani. 2011. Strategi Belajar Mengajar. Bandung: Pustaka Setia.

Keraf, Gorys. 1997. Komposisi: Sebuah Pengantar Kemahiran Bahasa. Flores: Nusa Indah.

Mantja, W. 2008. Profesionalisasi Tenaga Kependidikan: Manajemen Pendidikan. Malang: Elang Mas.

Mardapi, Djemari. 2000. Teknik Penyusunan Instrumen Tes dan Nontes. Yogyakarta: Mirta

Miles, B.B., dan A.M. Huberman. 1992. Analisa Data Kualitatif. Jakarta: UI Press Jakarta.

Moleong, L.J. 2005. Metodologi Kualitatif Edisi Revisi. Bandung: PT Remaja Rosdakarya.

Sugandi, A. 2004. Teori Pembelajaran. Semarang: UPT MKK Universitas Negeri Semarang.

Sukmadinata, Nana Sy. 2001. Pengembangan Kurikulum: Teori dan Praktik. Bandung: PT Remaja Rosdakarya. 
Syaiful Mujab

Sugiyono. 2012. Metode Penelitian Pendidikan (Pendekatan Kuantitatif, Kualitatif dan $R$ \& $D$ ). Bandung: Alfabeta.

Suharsimi, Arikunto dan Cepi Safruddin Abdul Jabar. 2010. Evaluasi Pendidikan: Pedoman Teoretis Praktis Bagi Mahasiswa dan Praktisi Pendidikan. Jakarta :Bumi Aksara.

Swearingen, R. 2006. A Primer: Diagnostik, Formative and Summative Assessment. 